Joanna Ludwiczak

Uniwersytet Łódzki

\title{
Książka obrazkowa - nowocześnie zaprojektowana książka dla dzieci
}

„Istnieją przedmioty, które już w odległej przeszłości osiągnęły swoją idealną formę, na przykład: siodło, nożyczki, guzik. Rozwój książki także już dawno się zakończył, [...] książka sprzed stu pięćdziesięciu lat jest równie »funkcjonalna«, jak współczesna”" . Ta niezwykle trafna teza opublikowana w 1946 roku przez ojca "nowej typografii” Jana Tschicholda nawet dziś, w dobie e-booków i Internetu, wciąż pozostaje aktualna. Jak przekonuje Umberto $\mathrm{Eco}^{2}$, książka podobnie jak koło, raz wynaleziona nie zniknie, a świat internetowych mediów nie jest w stanie zagrozić temu najdoskonalszemu i najbardziej ergonomicznemu nośnikowi.

Rozwijające się przez lata nowe możliwości technologiczne druku nadały produkcji książek masowy charakter, co w wielu przypadkach spowodowało pogorszenie dbałości wydawców o estetykę, jakość i rzetelność treści. Począwszy od lat dziewięćdziesiątych XX wieku znaczna rzesza rodzimych wydawców dosyć powierzchownie traktuje aspekty wizualne oferowanych publikacji. W dużej mierze zarzut ten dotyczy książek dla najmłodszych, które bardzo często powielają estetykę telewizyjnych kreskówek. Niemiecki pedagog i psycholog Christian Rittelmeyer zwraca uwagę na fakt, że

dzieci w wieku przedszkolnym i wczesnoszkolnym są całkiem bezbronne wobec masowych ([...] i pod wieloma względami szkodliwych) wpływów współczesnego przemysłu kulturowego - ma to miejsce zawsze wtedy, kiedy rodzice nie wspierają swoich dzieci w ich powolnym rozwoju i dojrzewaniu i nie kształtują w nich krytycyzmu i twórczego oporu ${ }^{3}$.

\footnotetext{
${ }^{1}$ J. Tschichold, Co nam zostało z tamtych lat, tłum. J. Jedliński, [w:] red. P. Dębowski, J. Mrowczyk (red.), Widzieć/Wiedzieć, Kraków 2011, s. 64.

${ }^{2}$ Zob.: J.-C. Carrière, U. Eco, Nie myśl, że książka zniknie, tłum. J. Kortas, Warszawa 2010.

${ }^{3}$ Ch. Rittelmeyer, Dzieciństwo w opresji. Pomiędzy przemystem kulturowym a technokratycznymi reformami szkolnictwa, tłum. B. Kowalewska z wykorzystaniem tłum. A. Murzyna, Kraków 2009, s. $16-17$.
} 
Otaczająca dziecko przestrzeń, do której zewsząd wdzierają się wytwory konsumpcyjnego świata, nie pozostaje bez znaczenia wobec dziecięcego doświadczania rzeczywistości oraz kształtowania wrażliwości i to nie tylko estetycznej. Przyzwyczajanie najmłodszych do dobrze zaprojektowanych i zilustrowanych książek może w przyszłości zaowocować wypracowaniem pozytywnych nawyków i przygotowaniem do świadomego odbioru sztuki, zarówno wysokiej, jak i popularnej ${ }^{4}$. Wzrostowi kultury estetycznej najmłodszych sprzyja zaobserwowane obecnie ożywienie na polskim rynku książek dla dzieci. Ostatnia dekada przyniosła powstanie niewielkich, lecz cieszących się stale rosnącym uznaniem wydawnictw, które publikują z wielką dbałością zarówno o stronę estetyczno-artystyczną, jak i literacko-merytoryczną. Również w katalogach dużych wydawnictw publikujących książki z rozmaitych dziedzin coraz częściej pojawiają się ambitne pozycje skierowane do dziecięcego odbiorcy ${ }^{5}$. Anna Machwic-Adamkiewicz zauważa, że

[...] o polskich książkach dla dzieci znowu zaczyna się mówić w kontekście sukcesu, a nie wyłącznie ubolewania nad marnością tego sektora wydawniczego. Na pewno przyczyniły się do tego laury naszych twórców na międzynarodowych przeglądach. I chociaż o sukcesach polskiej książki dla dzieci wciąż raczej milczą mainstreamowe media, to obszernie komentują je branżowe czasopisma (m.in. „Ryms”) i strony internetowe (np. www.polskailustracjadladzieci.pl). Publikują wywiady z autorami i ilustratorami, recenzje książek i gloryfikują ilustratorów nagradzanych w międzynarodowych konkursach ${ }^{6}$.

Coraz większym zainteresowaniem i tematem swoistego dyskursu wśród autorów książek dla dzieci, ilustratorów, wydawców, a także literaturoznawców i pedagogów, cieszy się gatunek książki obrazkowej. Pomysłowe, pięknie wydane książki o niebanalnej szacie graficznej wzbudziły także zainteresowanie wielu rodziców - o czym świadczyć może ich aktywne uczestnictwo w społecznościach internetowych promujących pu-

${ }^{4}$ Zob.: B. Górecka, Magia obrazu, czar ilustracji - o dobrej modzie na piękna ilustrację w ksiązkach dla dzieci, Poznań 2010.

${ }^{5}$ Zob.: A. Machwic-Adamkiewicz, Co powiedzieć dziecku?, „2+3D. Grafika plus produkt” 2012, $\mathrm{nr} 4(45)$, s. 18. Jako przykłady polskich wydawnictw zasłużonych w ostatnich latach w dziedzinie książki dla dzieci autorka wymienia małe oficyny skupiające się wokół polskich autorów (Czerwony Konik, Dwie Siostry, Ezop, Literatura, Muchomor, Wytwórnia), zagranicznych twórców (EneDueRabe, Format, Tatarak, Zakamarki, Hokus-Pokus, Tako) oraz duże wydawnictwa, które w ostatnich latach włączyły do swojej oferty ambitne pozycje dla dziecięcego odbiorcy (Media Rodzina, Nasza Księgarnia, Znak, W.A.B.).

${ }^{6}$ Ibidem, s. 31. 
blikacje dla dzieci (np. blogi, fora, fan page ${ }^{7}$ ) oraz w wydarzeniach z nimi związanych (np. warsztaty z ilustratorami, targi książek dla dzieci, wystawy pokonkursowe książek autorskich itp.). Wciąż jednak daleko nam do krajów anglosaskich, czy krajów Europy Zachodniej, gdzie książka obrazkowa od lat siedemdziesiątych XX wieku z nieustającym powodzeniem gości na półkach księgarń otoczona fachową krytyką w postaci regularnych recenzji w liczących się mediach, a co najważniejsze, zyskała status elementu niezbędnego w edukacji dziecka.

Co kryje się pod pojęciem książki obrazkowej? Ogólnie można przyjąć, że to książka o niewątpliwych walorach artystycznych, charakteryzująca się przemyślanym i spójnym projektem graficznym, typograficznym i edytorskim. Istotną rolę odgrywają również właściwości fizyczne książki, takie jak materiały, z których ją wykonano, oraz zastosowane techniki uszlachetniające. W parze $\mathrm{z}$ dobrym wzornictwem idzie twórczo podjęty temat - nie zawsze łatwy i banalny - nastawiony na spostrzegawczość i inteligencję odbiorcy - tak dorosłego, jak i dziecka. Bardzo często książki obrazkowe stanowią realizacje autorskie, od początku do końca zaprojektowane przez jednego twórcę. W wielu przypadkach są owocem ścisłej współpracy autora tekstu i ilustratora, lub też powstają dzięki inspiracji istniejącym już tekstem zaczerpniętym z literatury dziecięcej. Zawsze jednak charakteryzują się spójnością ogólnej koncepcji wszystkich elementów, od ilustracji i typografii, poprzez treść, aż po format, gramaturę papieru, rodzaj oprawy itp.

Jak pisze Małgorzata Cackowska, „pośród badaczy książki obrazkowej, pomimo różnic $\mathrm{w}$ podejściu, istnieje zgoda w sprawie pojmowania formy książki obrazkowej jako tej, która jest złożona $\mathrm{z}$ dwu sposobów przedstawiania, dwu reprezentacji - obrazów i słów - stanowiących jeden kulturowy tekst". Między ilustracją i tekstem istnieje nierozerwalna więź, która narzuca ich całkowitą zależność. Warstwa słowna bez obrazu przestaje być czytelna, choć bywa, że sama przybiera ilustracyjną formę, bądź też występuje znikomo. Zespolone słowo i obraz tworzą nowy rodzaj komunikatu wizualnego, pozwalając na jednoczesne przedstawienie przedmiotów, zdarzeń i pojęć abstrakcyjnych, trudnych do zdefiniowania wyłącznie przy użyciu języka plastyki.

\footnotetext{
${ }^{7}$ Ang. fan page - internetowa strona na portalu społecznościowym promująca markę, wydarzenie, osobę publiczną itp.

${ }^{8}$ M. Cackowska, Czym jest książka obrazkowa? O pojmowaniu ksiażki obrazkowej w Polsce - część II , „Ryms” 2009, nr 6, s. 14.
} 
W literaturze obcojęzycznej nie brakuje definicji opisujących gatunek książki obrazkowej. Według Barbary Bader, książka obrazkowa (ang. picturebook)

jest tekstem, ilustracjami i całościowym projektem; może być wykonana ręcznie albo stanowić komercyjny produkt; jest społecznym, kulturowym i historycznym dokumentem, a przede wszystkim jest doświadczeniem dla dziecka. Jako forma sztuki zależy od współbrzmienia obrazów i słów pokazywanych symultanicznie w każdej rozkładówce i dramatyzmu przewracania stron. Książka obrazkowa we właściwy sobie sposób ma nieograniczone możliwości ${ }^{9}$.

W polskiej literaturze naukowej wciąż brakuje wyczerpującej definicji książki obrazkowej. Pojawiające się w nielicznych słownikach wyjaśnienia tego terminu nie odpowiadają jej rzeczywistemu i współcześnie funkcjonującemu zakresowi pojęciowemu. Najbardziej trafną jak dotąd definicję, sformułowaną przez Janinę Wiercińską w latach siedemdziesiątych ubiegłego wieku, niemal zupełnie w późniejszych polskich opracowaniach zignorowano, co w konsekwencji mogło wpłynąć na brak utrwalenia się pojęcia książki obrazkowej i nieobecność tego znamiennego gatunku na rodzimym rynku wydawniczym. We wspomnianej definicji opisuje się książkę obrazkową jako

specyficzną formę książki dla małego dziecka, mającą odpowiedniki w języku niemieckim i angielskim w słowach „Bilderbuch” i „picture-book” i opierającą się przede wszystkim na wymowie obrazków. Dla powstania takiej książki warstwa słowna, przeważnie skromna, nieraz nikła, jest tylko pretekstem.[...] to taka postać książki dla dziecka, w której podstawowym elementem wypowiedzi jest obraz, gdzie strona wizualna, jeśli nie stanowi celu głównego, wiąże się z tekstem na zasadach równouprawnienia, gdzie pisarz i rysownik (jeśli nie jest to jedna i ta sama osoba) tak ściśle ze sobą współpracują, że istnienie tekstu jest uwarunkowane obrazem i na odwrót ${ }^{10}$.

Osoby zajmujące się współcześnie zagadnieniem książki dla dzieci często podkreślają chaos pojęciowy, jaki panuje w polskim nazewnictwie wokół książki obrazkowej ${ }^{11}$. Wielu wydawców, badaczy zjawiska oraz auto-

${ }^{9}$ B. Bader, American Picturebooks: From „Noah's Ark” to „The Beast Within”, New York 1976, s. 1. Cyt. za: M. Cackowska, Czym jest ksiażzka obrazkowa..., część II, s. 15.

${ }^{10}$ J. Wiercińska, Sztuka i ksiązka, Warszawa 1986, s. 76. Cyt za: M. Cackowska, Czym jest książka obrazkowa? O pojmowaniu książki obrazkowej w Polsce - część III, „Ryms” 2009/2010, nr 8, s. 12-13.

${ }^{11}$ Por.: audycja A. Łapkiewicz „Notatnik Dwójki” pt. „Kto się boi książek dla dzieci”, Program Drugi Polskiego Radia, www.polskieradio.pl/8/1594/Artykul/746860/ (dostęp: 20.12.2012); I. Chmielewska, Książka obrazowa - próba nowego pojęcia, http://forum.gazeta.pl/forum/w,16375 ,84622245,84622245,Ksiazka_OBRAZOWA_proba_nowego_pojecia_html (dostęp: 3.12.2012); M. Cackowska, Czym jest książka obrazkowa? O pojmowaniu ksiązki obrazkowej w Polsce - czesść I, „Ryms” 2009, nr 5. 
rów na czele z Iwoną Chmielewską ${ }^{12}$ proponuje termin "książka obrazowa” i unika zdrobnienia „obrazek”, które ich zdaniem wpływa niekorzystnie na właściwe postrzeganie tego gatunku i ujmuje wartość artystyczną wspaniałej warstwie graficznej książek.

W potocznej świadomości społeczeństwa głęboko zakorzeniły się pewne stereotypy dotyczące nie tylko książek, ale i całego „przemysłu dziecięcego". Rozumienie potrzeb dziecka przez dorosłych często tożsame jest $\mathrm{z}$ infantylizacją, naiwnością przedstawień oraz przesłodzoną wizją rzeczywistości. W wypowiedzi Józefa Wilkonia czytamy, że dziecko „karmione” tak uproszczonymi obrazami

[...] przestaje reagować na piękno świata, widzi świat okaleczony. Nie czuje futerkowości zwierząt, nie czuje bogactwa materii [...] Dziecku [przyp. J. L.] potrzebne jest wszystko, od strachu, lęku po optymizm. [...] Stopniowanie tych emocji bardzo dobrze robi. [...] Odrobina lęku jest jak szczepionka przeciwko lękom, jakie stwarza dorosłe życie ${ }^{13}$.

Książki obrazkowe, w których często operuje się przedstawieniami symbolicznymi i wykorzystuje się różne rodzaje estetyki, dają możliwość pokazania dziecku zarówno pięknych aspektów rzeczywistości, jak i tych negatywnych. W ten sposób przyczyniają się one do pełniejszego i głębszego zrozumienia świata, pomagają budować system wartości, nazywać uczucia i stany emocjonalne (np. miłość, szczęście, przywiązanie), a także wyjaśnić i zrozumieć trudne tematy (np. choroba, niepełnosprawność, śmierć, emigracja, wojna). Komunikat oparty na dwóch przenikających się płaszczyznach narracji - obrazie i słowie - staje się dla małego odbiorcy bardziej przystępny i wpływa na poszerzanie zdolności kognitywnych. Obcowanie dziecka $\mathrm{z}$ wizualnie i tekstowo konsekwentnie skomponowaną historią znacznie pobudza wyobraźnię, kreatywność i abstrakcyjne myślenie. W licznych opracowaniach książka obrazkowa traktowana jest jako forma wypowiedzi artystycznej, w związku z czym można uznać ją za znakomity obszar inicjacji kulturalnej w postaci małej galerii sztuki i pierwszego kontaktu z literaturą. Znawca literatury dziecięcej Grzegorz Leszczyński twierdzi, że „ilustrowana przez doświadczonych artystów [...] i twórców młodego pokolenia [...] książka wprowadza dziecko w żywioł sztuki współczesnej, daje mu klucz do rozumienia Dudy-Gracza, Hasiora,

\footnotetext{
${ }^{12}$ Iwona Chmielewska (ur. 1960) - jedna z najbardziej uznanych na świecie polskich autorek książki obrazkowej.

${ }^{13}$ Jestem malarzem nocy, wywiad Ewy Ziemer z Józefem Wilkoniem, http://ryms.pl/artykul_ szczegoly/134/jestem-malarzem-nocy.html (dostęp: 12.02.2013).
} 
czy Nowosielskiego"14. Wzbogacenie domowej biblioteczki o wartościowe książki dla dzieci daje sposobność kontaktu ze sztuką na wyciągniecie ręki i w dowolnym momencie, a doświadczenia dziecka staną się tym bogatsze, im częściej towarzyszyć mu będzie dorosły członek rodziny. Pośrednictwo osoby dorosłej w procesie odbioru książki przez dziecko jest niezwykle ważne i wręcz nieodzowne, ponieważ w pierwszej kolejności to rodzice kształtują najbliższe materialne otoczenie dziecka, dokonując wyborów zgodnie $\mathrm{z}$ własnymi preferencjami. Problemem jest niestety pokutująca w świadomości rodziców i opiekunów wspomniana już infantylizacja dziecięcego świata, którą masowo wykorzystują producenci nie tylko książek, ale i innych artykułów dla dzieci. Wiedza o nowocześnie i twórczo zaprojektowanych produktach dla dzieci (w tym książkach obrazkowych) wciąż pozostaje poza zasięgiem przeciętnego rodzica i nie jest w stanie przebić się przez ogrom zalewających rynek produktów masowych. Podobna nieświadomość dotycząca książki obrazkowej kształtuje się wśród nauczycieli wychowania przedszkolnego, którzy w określaniu predylekcji obrazowych dzieci najczęściej opierają się na własnej intuicji i doświadczeniu. Małgorzata Cackowska ${ }^{15}$ prowadząca badania w tym zakresie wskazuje na fakt, że zaniedbania dotyczące postulatów edukacji przez sztukę widoczne są już na poziomie kształcenia przyszłych pedagogów. O ile trudno podważyć znaczenie dydaktyczne literatury dziecięcej w edukacji przedszkolnej, o tyle książka obrazkowa w polskich programach nauczania jest obszarem zupełnie nieznanym. To niezwykle wartościowe medium, w którym sztuka spotyka się z codziennością, dysponuje szerokim potencjałem oddziaływania, a przy właściwym wykorzystaniu może odegrać niebagatelną rolę w procesie wychowania przyszłych świadomych odbiorców sztuki i szeroko pojętej kultury. Aby jednak książka obrazkowa w pełni mogła realizować swoje funkcje i zadania, konieczna jest edukacja, współpraca i twórczy dialog wszystkich osób pośredniczących w swoistej wędrówce książki do dziecka, począwszy od twórców (autorów tekstu, ilustratorów, grafików), przez krytyków, wydawców, bibliotekarzy, aż po nauczycieli i rodziców.

${ }^{14}$ Czytać na przekór światu, wywiad Beaty Kęczkowskiej z prof. Grzegorzem Leszczyńskim http://warszawa.gazeta.pl/warszawa/1,34861,9992494,Czytać_na_przekor_swiatu.html (dostęp: 18.12.2012).

${ }^{15}$ Zob.: Po co nam wiedza o książce dla dzieci, wywiad A. Sikorskiej-Celejewskiej z dr M. Cackowską, http://www.qlturka.pl/czytelnia,literatura,po_co_nam_wiedza_o_ksiazce_dla_dzieci_-_ rozmowa_z_dr_malgorzata_cackowska,6005.html (dostęp: 20.12.2012). 


\section{Bibliografia}

Cackowska M., Czym jest książka obrazkowa? O pojmowaniu książki obrazkowej w Polsce - część I, „Ryms” 2009, nr 5.

Cackowska M., Czym jest książka obrazkowa? O pojmowaniu książki obrazkowej w Polsce - część II, „Ryms” 2009, nr 6.

Cackowska M., Czym jest książka obrazkowa? O pojmowaniu książki obrazkowej w Polsce - część III, „Ryms” 2009/2010, nr 8.

Carrière J.-C., Eco U., Nie myśl, że książki znikną, tłum. J. Kortas, Warszawa 2010.

Czytać na przekór światu, wywiad Beaty Kęczkowskiej z prof. Grzegorzem Leszczyńskim, http://warszawa.gazeta.pl/warszawa/1,34861,9992494,Czytać_na_przekor_swiatu. html (dostęp: 18.12.2012).

Dębowski P., Mrowczyk J., Widzieć/wiedzieć, Kraków 2011.

Jestem malarzem nocy, wywiad Ewy Ziemer z Józefem Wilkoniem, http://ryms.pl/artykul_ szczegoly/134/jestem-malarzem-nocy.html (dostęp: 12.02.2013).

Machwic-Adamkiewicz A., Co powiedzieć dziecku?, „2+3D. Grafika plus produkt” 2012, nr 4(45), s. 18-33.

Rittelmeyer Ch., Dzieciństwo w opresji. Pomiędzy przemysłem kulturowym a technokratycznymi reformami szkolnictwa, tłum. B. Kowalewska z wykorzystaniem tłum. A. Murzyna, Kraków 2009.

Wiercińska J., Sztuka i książka, Warszawa 1986. 